\title{
ESSENTIAL BENIGN FRUCTOSURIA
}

\author{
BY \\ Z. LARON \\ From the Paediatric Metabolic and Endocrine Clinic and the Rogoff Medical Research Institute, \\ Beilinson Hospital, Petah Tikva, Israel
}

(RECEIVED FOR PUBLICATION JULY 13, 1960)

Essential fructosuria is a benign inborn error of metabolism characterized by an inability to utilize fructose completely (Hsia, 1959). It was first described in 1876 independently by Zimmer and Czapek (Zimmer, 1876; Czapek, 1876). Sachs, Sternfeld and Kraus in 1942 reviewed 39 proven cases. Since then 10 more cases have been reported (Trivette and Anderson, 1948; Ulgen, 1952/53; Levy, 1953; Faron, 1955; Lenzner, 1956; Cantoni and Klinger, 1957; B. Verbin, 1959, personal communication). Lasker (1941) estimated that fructosuria occurred once in every 120,000 births and supplied evidence that the disturbance was inherited by virtue of an autosomal recessive gene.

In the present paper we wish to report a case of essential fructosuria with a study of the influence of hyper- and hypoglycaemic agents on the fructosuria.

\section{Case Report}

A Jewish, Tripoli-born girl, $11 \frac{1}{2}$ years of age, was admitted to the hospital on December 28, 1957, suffering from acute rheumatic fever. Her parents and three other siblings were healthy. The family history and the parent's past history were unrevealing. The diagnosis of rheumatic fever was confirmed and she was treated with cortisone and salicylates. During hospital treatment the urine was found positive for sugar on repeated occasions. On a standard hospital diet she excreted 2.5 to $12 \mathrm{~g}$. of sugar per 24 hours. No acetone was found. Fasting blood sugar level was normal and an oral glucose tolerance test $(3 \mathrm{~g}$. per $\mathrm{kg}$. body weight) performed after discontinuation of cortisone, showed the following values: Fasting blood sugar, $96 \mathrm{mg}$. $/ 100 \mathrm{ml}$; after 30 minutes, $211 \mathrm{mg} . / 100 \mathrm{ml}$; after 60 minutes, $150 \mathrm{mg} . / 100 \mathrm{ml}$; 120 minutes, $145 \mathrm{mg} . / 100 \mathrm{ml}$; 180 minutes, $109 \mathrm{mg} . / 100 \mathrm{ml}$. Serum total proteins were $7 \cdot 24 \mathrm{~g}$. \%, albumin $4 \cdot 8 \mathrm{~g}$. $\%$, blood urea $36 \mathrm{mg}$. $/ 100 \mathrm{ml}$. Liver function tests were normal.

According to the tests listed in the Table and the paper chromatography in Fig. 1, the sugar excreted in the urine was identified as fructose. It was demonstrated by the Lasker test (1941) that abstaining from fructosecontaining food prevented the fructosuria. Ingestion of dextrose did not cause fructosuria. Upon ingestion of $50 \mathrm{~g}$. fructose the sugar appeared in the urine within a short time.
Following discharge the patient made an uneventful recovery at home. Further investigations were performed on an ambulatory basis, the body weight of the patient at that time being $40 \mathrm{~kg}$.

\section{Methods}

Loading tests were performed after the following preparation: (a) supper on the previous evening did not include fruits, vegetables or sugar; $(b)$ patient fasted for 14 hours; $(c)$ the control urine specimen before the test was sugar-free. The dose of fructose administered was $1 \mathrm{~g}$. per $\mathrm{kg}$. body weight unless otherwise stated.

Total blood sugar was estimated by the method of Rappaport and Eichhorn (1950), blood fructose by the method of Patterson and Herbert as modified by Thompson and others (Behrendt, 1949). Blood dextrose was calculated by subtracting blood fructose from total blood sugar. Urine was collected hourly by indwelling catheter. As the sugar in the urine had been shown to be fructose only, urinary frustose was determined by the method of Fehling, but each specimen was also checked with glucose oxidase paper (Clinistix-Ames). Several urine specimens were examined also by paper chromatography (butanol acetic acid). Serum inorganic phosphorus was measured by the method of Fiske and Subbarow (1925).

\section{Results}

Fig. 2 shows the curve of blood fructose concentration in the patient after an oral and intravenous load, as compared to the blood fructose curve in a normal child of the same age after an oral fructose load. It is seen that the blood fructose level in the control subject after the oral fructose load, increases slightly and returns gradually to the fasting level after four hours. In the patient the same oral dose

TABLE

IDENTIFICATION OF URINARY SUGAR

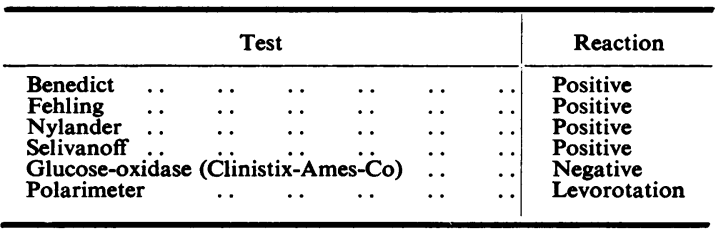




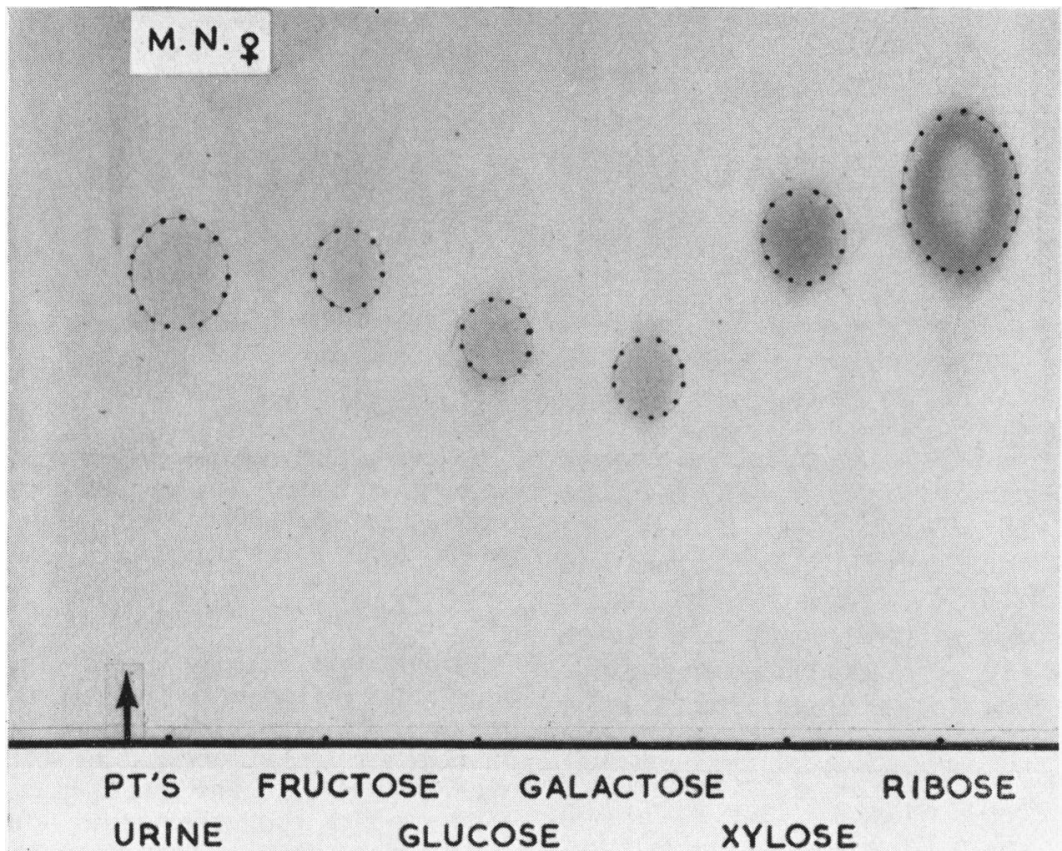

FIG. 1.-Paper chromatography of patient's urine and sugar standards. (Butanol-acetic acid; 16 hours.)

FRUCTOSE TOLERANCE

-Dose: I g./ kg.BodyWeight

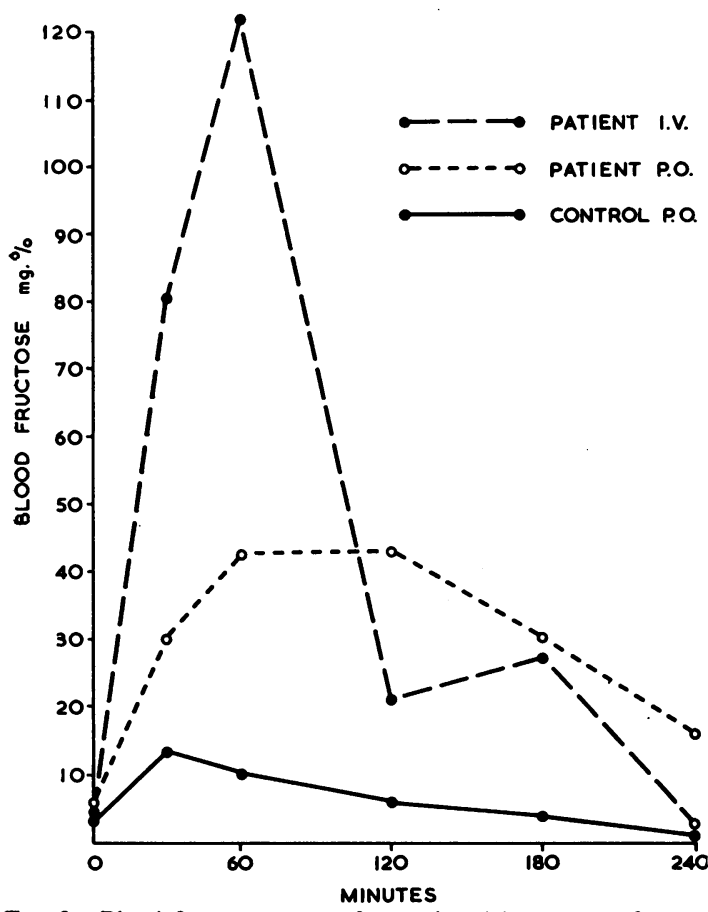

Fig. 2.-Blood fructose curves after oral and intravenous fructose administration to the patient and oral fructose administration to a control subject. of fructose per unit body weight caused a marked increase in the blood fructose level. Four hours after the start of the test, the concentration was still three times the fasting value. After an intravenous load, given by continuous drip during one hour, a blood fructose concentration of $120 \mathrm{mg}$. \% was reached. A rapid decrease occurred after stopping the infusion and at four hours the normal fasting level was regained. After the oral fructose load in the patient, fructose appeared rapidly in the urine and was excreted during a period of three hours in a total amount of $5 \cdot 2 \mathrm{~g}$. or $13 \%$ of the administered dose (Fig. 3). The highest excretion occurred during the second hour. No fructose appeared in the urine of the control subject. After intravenous administration fructose was excreted by the patient in the urine only during the first two hours (Fig. 4), in a total amount of $5.91 \mathrm{~g}$. or $16 \%$ of the dose.

Further fructose loading tests were performed by raising or lowering the blood dextrose concentration. When $60 \mathrm{~g}$. dextrose and $40 \mathrm{~g}$. of fructose were given simultaneously by mouth and the patient's urine and blood examined over a period of four hours, the total blood sugar rose to a maximum of 200 mg. $\%$, representing the sum of dextrose and fructose concentration (Fig. 5), the highest blood fructose concentration being $50 \mathrm{mg} . / 100 \mathrm{ml}$. Fructose was excreted throughout the four hours of the experiment: $8 \cdot 8 \mathrm{~g}$. or $21 \cdot 2 \%$ of the fructose load. The 


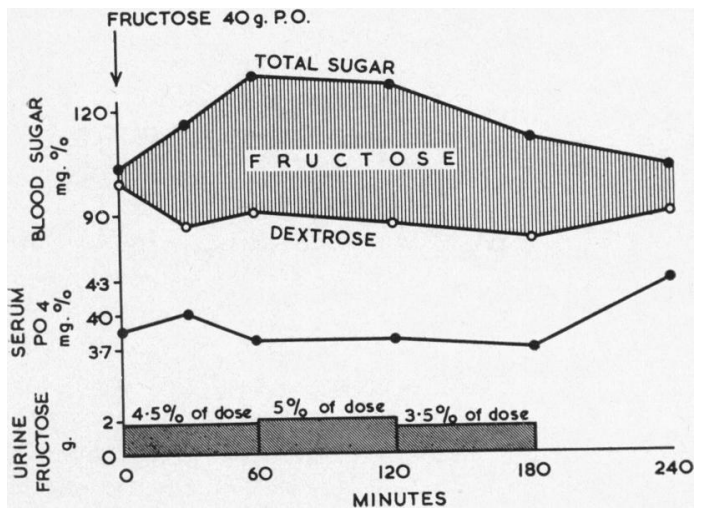

Fig. 3.-Total blood sugar, fructose and dextrose concentrations and urine fructose excretion after an oral fructose load to the patient.

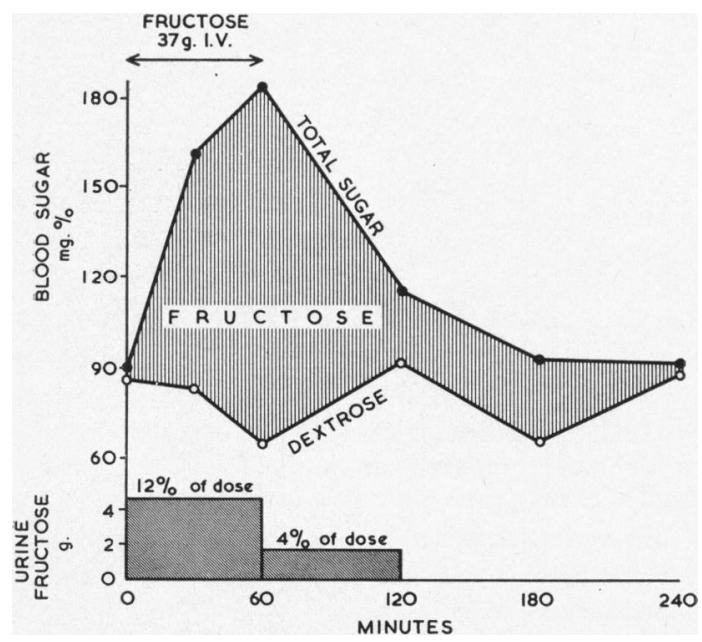

Fig. 4.-Total blood sugar, fructose and dextrose concentrations and urinary fructose excretion after an intravenous fructose load.

maximum excretion occurred in the second hour. No dextrose appeared in the urine.

When hyperglycaemia was induced by the injection of glucagon ( $2 \mathrm{mg}$., intramuscularly, Fig. 6), the fructosuria also continued throughout the four hours of the test; $4.46 \mathrm{~g}$. corresponding to $11 \%$ of the load were excreted, with the maximum excretion in the second hour. No dextrose appeared in the urine.

Lowering the blood dextrose concentrations by either insulin (4 units intravenously, Fig. 7), or by tolbutamide ( $2 \mathrm{~g}$. given by mouth, Fig. 8 ), the blood fructose curve was similar to that obtained with oral fructose alone, but the quantity of fructose excreted in the urine over three hours was smaller: $2.4 \mathrm{~g}$., corresponding to $6 \%$ of the load in both instances.

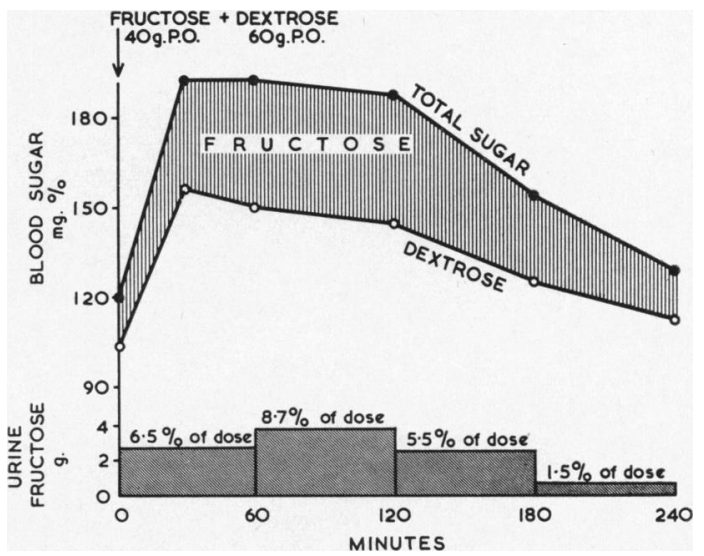

Fig. 5.-Total blood sugar, fructose and dextrose concentrations and urine fructose excretion after a simultaneous oral load of fructose and dextrose.

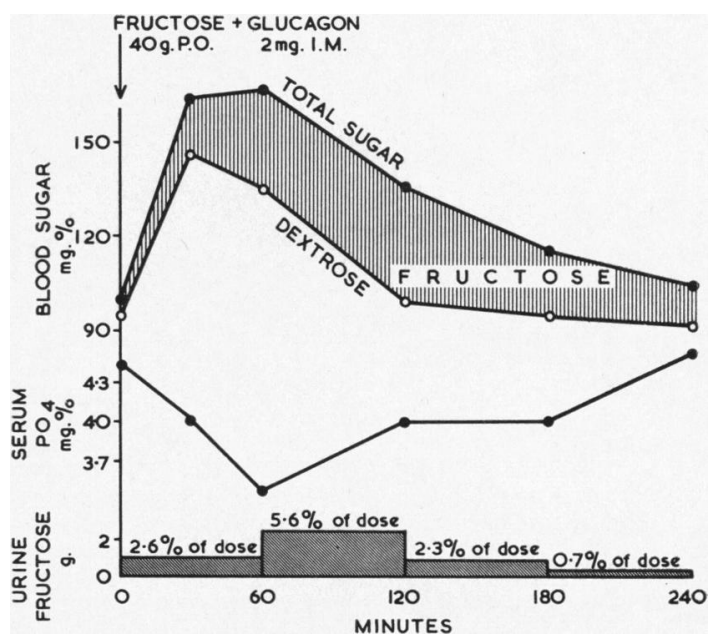

FIG. 6.-Total blood sugar, fructose, dextrose and serum inorganic phosphorus concentrations and urine fructose excretion after an oral fructose load and simultaneous intramuscular injection of glucagon.

An intravenous injection of $250 \mathrm{mg}$. hydrocortisone did not influence the blood fructose levels nor urine fructose excretion after an oral fructose load.

In order to determine the maximum amount of fructose which our patient was capable of metabolizing, intravenous infusions of fructose of different concentrations were given at a constant rate and the urine tested for the appearance of sugar. When a $1 \%$ solution was infused over one hour, so as to deliver $40 \mathrm{mg}$. fructose per minute, no sugar appeared in the urine. When a $2 \%$ solution of fructose was infused, so as to deliver $60 \mathrm{mg}$. fructose per minute, there was reduction 


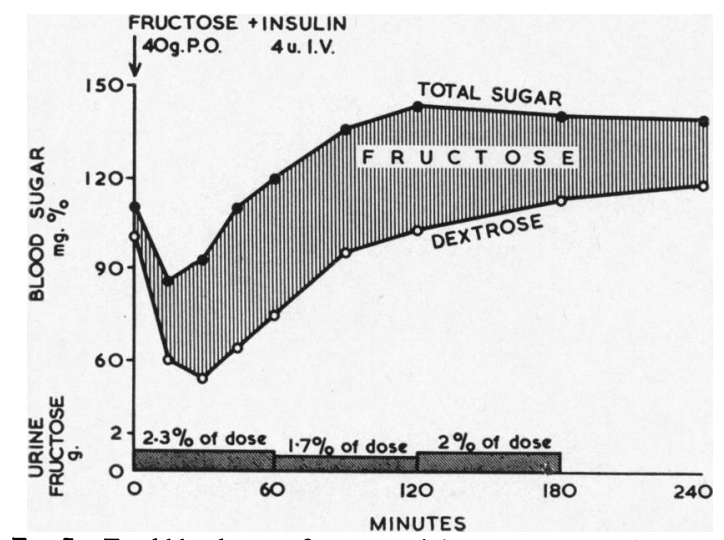

Fig. 7.-Total blood sugar, fructose and dextrose concentrations and urine fructose excretion after an oral fructose load and simultaneous intravenous injection of insulin.

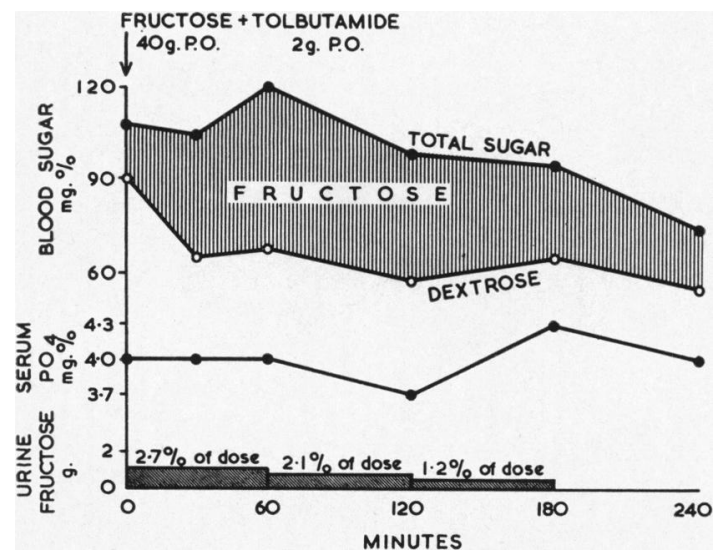

Fig. 8.-Total blood sugar, fructose, dextrose and serum inorganic phosphorus concentrations and urine fructose excretion after an oral fructose load and simultaneous tolbutamide administration.

of Nylander solution by the urine during the period of infusion and for one hour after its termination. The excretion of fructose was confirmed by chromatography and polarimetry. The Fehling and bicarbonate test remained negative throughout, indicating that the quantity of fructose excreted as a result of this load was very small, such as to be detected only by sensitive tests.

Upon examining the relationship of blood fructose and dextrose concentrations in the simple and double loading tests performed (Figs. 3-8), it is seen that blood fructose concentrations were not influenced by changes in blood dextrose. When fructose was administered alone (Figs. 3 and 4), a slight drop of the blood dextrose concentration was observed initially. Serum inorganic phosphorus concentration, usually, but not always, varied inversely with the blood dextrose level.
The urine of the patient's three siblings, her grandparents, parents, uncles and aunts and the latter's children was repeatedly tested after a fructose load (honey). Fructosuria was never detected.

\section{Discussion}

In the normal individual fructose is metabolized at a faster rate than glucose (Albanese, Felch, Higgons, Vestal and Stephanson, 1952; Mendeloff and Weichselbaum, 1953). In liver disease there is a disturbance in fructose metabolism which may lead to the excretion of this sugar in the urine (Strauss, 1901 (cited by Steinitz, 1939); Steinitz, 1937). Recently we have reported the occurrence of fructose among other sugars in the urine of a baby suffering from the nephrotic syndrome (Laron, Yonis, Tissibov and Boss, 1960).

In the past 85 years, 50 cases (including the present one) of otherwise normal individuals who excreted fructose in the urine have been described (Sachs et al., 1942; Trivette and Anderson, 1948; Ulgen, 1952/53; Levy, 1953; Faron, 1955; Lenzner, 1956; Cantoni and Klinger, 1957; B. Verbin, 1959, personal communication). As this was a symptomless manifestation, the finding was incidental and was made at different ages. In some instances it occurred in father and child or in siblings. Considering the present routine to test urine for sugar with paper strips impregnated with glucose oxidase, cases of essential benign fructosuria are likely to be overlooked, and the incidence therefore may be higher than reported. The proportion of Jews in the known and proven cases of this disorder is high, constituting 18 out of 50 cases.

It is assumed that the pathogenesis of essential benign fructosuria is due to a congenital lack of the hepatic enzyme fructokinase which catalyses the conversion of fructose to fructose $1-\mathrm{PO}_{4}$ (Renold and Thorn, 1955). In all of the cases of essential benign fructosuria reported, it was observed that only about one-tenth of the fructose load is excreted in the urine. It can be inferred, therefore, that besides the pathway mediated by fructokinase there must be alternative ways for the utilization of fructose. Evidence for this is the demonstration of conversion of fructose to fructose $6-\mathrm{PO}_{4}$ in the presence of hexokinase and ATP in the brain and muscles (Slein, Cori and Cori, 1950). The inhibitory action of glucose on the phosphorylation of fructose by hexokinase (Renold and Thorn, 1955), may explain why the addition of dextrose in earlier studies (Steinitz, 1931; Silver and Reiner, 1934) and in the present one was accompanied by prolonged fructosuria and excretion of a larger amount of fructose. The action of glucagon prolonging the 
period of fructosuria without increasing the total amount of sugar excreted, may be explained by the lesser degree of hyperglycaemia caused by the drug, as compared to that following a combined dextrose and fructose load. Whether the decreased fructose excretion during the hypoglycaemia induced by insulin or tolbutamide, is due to greater availability of hexokinase in the tissue, is hypothetical. The ineffectiveness of insulin on the fructosuria noted by Silver and Reiner (1934), may have been due to the different route of administration and possibly less marked hypoglycaemia. In our patient about $50 \mathrm{mg}$. of fructose per minute could be metabolized by the alternative pathway, as found in experiments with constant intravenous infusion of fructose.

In recent years a malignant form of fructosuria has been described by Chambers and Pratt (1956) and Froesch, Prader, Wolf and Labhart (1959). This 'hereditary fructose intolerance' characterized by severe hypoglycaemia occurring upon ingestion of fructose was shown to be caused by a lack of the enzyme 1-phospho-fructaldolase.

\section{Summary}

A case of essential benign fructosuria in an 11-year-old Jewish girl is described.

Both hyperglycaemia induced by administration of dextrose or glucagon and hypoglycaemia induced by administration of insulin or tolbutamide affected the duration and/or the amount of fructose excreted in the urine after a fructose load.

The patient was able to metabolize up to $50 \mathrm{mg}$. of fructose per minute. Any amount in excess was excreted in the urine.

These findings are discussed in the light of the enzymatic disturbances invoked in this metabolic disorder.

The author is indebted to Mrs. F. Eichhorn and Dr. F. Rappaport (deceased) of the Laboratory of Clinical Chemistry for performing the paper chromatography and the polarimetric tests. Glucagon was kindly supplied by Dr. W. R. Kirtley of the Eli Lilly Research Laboratories, Indianapolis, U.S.A. During hospital treatment the patient was under the care of Drs. Z. Yonis and M. Gefman.

Prof. A. de Vries gave helpful criticism during the preparation of the paper.

\section{REFERENCES}

Albanese, A. A., Felch, W. C., Higgons, R. A., Vestal, B. L., and Stephanson, L. (1952). Utilization and protein-sparing action of fructose in man. Metabolism, 1, 20.

Behrendt, H. (1949). Diagnostic Tests for Infants and Children, p. 114. Interscience, New York.

Cantoni, M. and Klinger, R. (1957). Sulla levulosuria essenziale infantile. Minerva med. (Torino), 48, 1092.

Chambers, R. A. and Pratt, R. T. C. (1956). Idiosyncrasy to fructose. Lancet, 2, 340.

Czapek, F. (1876). Eine seltene Form von Diabetes mellitus. Prag. med. Wschr., 1, 265

Faron, C. (1955). A case of fructosuria. Harefuah, 48, 175.

Fiske, C. H. and Subbarow, Y. (1925). The colorimetric determination of phosphorus. J. biol. Chem., 66, 375.

Froesch, E. R., Prader, A., Wolf, H. P. and Labhart, A. (1959). Die hereditäre Fructose-intoleranz. Helv. paediat. Acta, 14, 99.

Hsia, D. Y. (1959). Inborn Errors of Metabolism. The Year Book Publishers, Chicago.

Laron, A., Yonis, Z., Tissibov, R. and Boss, I. (1960). Infantile nephrosis in two siblings. Ann, paediat (Basel). 195, 337.

Lasker, M. (1941). Essential fructosuria. Hum. Biol., 13, 51.

Lenzner, A. R. (1956). Fructosuria, report of a case. Ann. intern. Med., 45, 702

Levy, J. (1953). A case of laevulosuria. Harefuah, 44, 78.

Mendeloff, A. I. and Weichselbaum, T. E. (1953). Role of the human liver in the assimilation of intravenously administered fructose. Metabolism, 2, 450.

Rappaport, F. and Eichhorn, E. (1950). A rapid titrimetric method for determination of blood-sugar. Amer. J. clin. Path., 20, 834.

Renold, A. E. and Thorn, G. W. (1955). Clinical usefulness of fructose. Amer. J. Med., 19, 163.

Sachs, B., Sternfeld, L. and Kraus, G. (1942). Essential fructosuria. Amer. J. Dis. Child., 63, 252.

Silver, S. and Reiner, M. (1934). Essential fructosuria. Arch. intern. Med 54,412 .

Slein, M. W., Cori, G. T. and Cori, C. F. (1950). A comparative study of hexokinase from yeast and animal tissues. J. biol. Chem., 186, 763 .

Steinitz, H. (1931). Stoffwechseluntersuchungen bei Fructosurie. Deutsches Arch. klin. Med., 171, 401. (1937). Die Fructosebelastung als Leberfunktionsprüfung. Acta med. scand., 93, 98.

(1939). Untersuchungen zur Pathologie des FruktoseStoffwechsels. Reine Fruktosurie bei Geschwistern. Diabetes und Fruktose-Stoffwechsel. Gastroenterologia (Basel), 64, 334.

Strauss, H. (1901). Zur Funktionsprüfung der Leber. Dtsch. med. Wschr., 27, 757, cited by Steinitz, H., 1939.

Trivette, D. and Anderson, K. (1948). Essential fructosuria in two siblings. Amer. J. Dis. Child., 75, 88.

Ulgen, T. (1952/53). Drei Fälle von essentieller Laevulosurie. Istanbul. Contrib. Clin. Sci., 2, 286.

Zimmer, K. (1876). Levulose im Harn eines Diabetikers. Dtsch. med. Wschr., 2, 329 